\title{
The influence of long-term land reclamation on the microbiological properties of post-mining soils
}

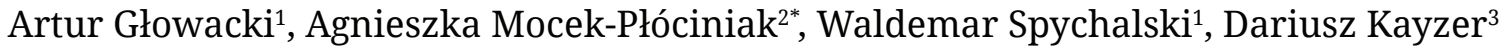 \\ ${ }^{1}$ Poznań University of Life Sciences, Department of Soil Science and Land Protection, Szydłowska 50, 60-656, Poznań, Poland \\ ${ }^{2}$ Poznań University of Life Sciences, Department of General and Environmental Microbiology, Szydłowska 50, 60-656, Poznań, Poland \\ ${ }^{3}$ Poznań University of Life Sciences, Department of Mathematical and Statistical Methods, Wojska Polskiego 28, 60-637, Poznań, Poland \\ * dr hab. inż. A. Mocek-Płóciniak, agnieszka.mocek-plociniak@up.poznan.pl, ORCID iD: https://orcid.org/0000-0002-7073-7732
}

Received: 03.06.2020

Accepted: 03.09.2020

Associated editor: A. Gałązka

\section{Keywords}

Soil microorganisms

Enzymatic activity

Regosols

Reclamation

\begin{abstract}
The aim of the study was to analyse the enzymatic activity of dehydrogenases, urease, alkaline phosphatase and proteases in post-mining soils. Moreover determined the count of heterotrophic bacteria, moulds, actinobacteria and bacteria of the Azotobacter sp. genus. The research was conducted between 2015 and 2017 in experimental areas of the Pątnów dump, which belongs to the Department of Soil Science and Land Reclamation, Poznań University of Life Sciences. Soil samples for analysis were collected at depths of 0-30 $\mathrm{cm}$ and $30-60 \mathrm{~cm}$. The first factor under analysis was two simplified crop rotation systems, i.e. a rapeseed and cereal system (alternating cultivation of wheat and winter rapeseed) and a forage and cereal system (the cultivation of alfalfa with grasses for four years followed by the growing of winter wheat for the next two years). The second factor under analysis was three sub-blocks with increasing mineral fertilisation levels: 0NPK, 1NPK and 2 NPK. The research results were analysed by means of one-way analysis of variance. Homogeneous groups were identified with the Tukey test at a significance level $a=0.05$. The Statistica 13.1 program was used for statistical calculations. The post-mining soils were classified as Calcaric Regosols (IUSS Working Group WRB, 2015). The microbiological activity of the soils exhibited high variability both in the growing season and in the subsequent years of the research. The forage and cereal crop rotation system had better effect on the soil microbiological and biochemical activity than the other system. Therefore, feed and cereal crop rotation is recommended for the reclamation of soils in internal post-mining dumps.
\end{abstract}

\section{Introduction}

The second half of the $20^{\text {th }}$ century saw in Poland intensive development of the mining industry and the processing of energy resources, rock materials and metal ores (Bender and Gilewska, 2004; Mocek-Płóciniak, 2018). This generated large areas of land requiring reclamation. At the time reclamation school originated in the Wielkopolska region. Prof. Jan Bender developed the concept of target plants, also known as the PAN (Polish Academy of Sciences) model (Gilewska, 1991; MocekPłóciniak, 2018). It was based on the assumption of interaction of abiotic and biotic factors, which enabled the development of productive soil from raw parent rock in the shortest time possible and with relatively low outlay (Gilewska, 1991; Karczewska, 2008). High mineral fertilisation was of key importance for the effectiveness of the method as it was necessary to regulate and improve the soil chemistry - rock extracted from the brown coal overburden. Another element of the reclamation proce- dure was regulation of the physical properties of soil. Agrotechnical treatments such as ploughing, post-harvest cultivation, and harrowing were applied, because they homogenise, aerate and stimulate the weathering of mineral soil material. Next, target crops such as winter rapeseed, winter cereals and alfalfa were introduced. These stages were always preceded by technical works, which were done to determine the location, type and formation of spoil tips. According to this concept, land reclamation significantly accelerates its economic use; agricultural reclamation - by at least 10 years and forest reclamation - by 20 years (Bender and Gilewska, 2004). As a result, soils with all attributes of biogenicity and productivity are formed. If there is no human interference in these processes, the transformation of raw parent materials into soil is very slow - it takes about 200-400 years (Podgaiski and Rodrigues, 2010; Saarsalmi et al., 2012).

Microorganisms, vegetation, animals and humans play an important role in the formation of soil and its functioning. Soil 
microorganisms participate in organic matter mineralisation, determine the fertility and biological productivity of soils, and affect their capability and yield of crops (Schmidt et al., 2005; Marinari et al., 2006; Mocek-Płóciniak, 2018). The count of microorganisms affects the function of the entire soil ecosystem, detoxification and the rate of reclamation processes. Enzymatic activity is another important parameter providing information about the state of the soil biological environment. It reflects the advancement of soil-formation processes (Bielińska et al., 2004; Gilewska and Płóciniczak, 2004; Bielińska and MocekPłóciniak, 2009; Bielińska et al., 2014), illustrates the trends of pedogenic processes in post-mining soils and enables assessment of the effectiveness of the applied reclamation treatments (Bielińska et al., 2000a, 2000b). Enzymatic activity is also important in soil diagnostics and it can be a reliable indicator of the evolution of Technosols (Mocek-Płóciniak, 2018).

The aim of this study was to measure the count of basic groups of soil microorganisms and the enzymatic activity in post-mining soils. Microbiological and biochemical indicators can be used to forecast the anthropogenic transformations of soils, which enable effective restoration of productivity in degraded soils, which were earlier the overburden of extracted minerals. Due to the fact that these parameters are more labile than the physical and chemical properties, samples were taken from the two crop rotation systems in the spring and autumn.

\section{Materials and methods}

\subsection{Study area}

The research was conducted between 2015 and 2017 in experimental areas belonging to the Department of Soil Science and Land Reclamation, Poznań University of Life Sciences, Poland, which were established in 1978. The fields are located on the inner spoil tip of the Pątnów open-pit mine, which is located in the north of the city of Konin, in the east of Greater Poland Voivodeship. The experimental field area of 20 ha was part of the inner spoil tip of the Pątnów open-pit mine. As mentioned before, land reclamation was based on the model developed by the Polish Academy of Sciences, which consisted in the biological transformation of the rocky ground into soil. The field experiment was conducted with the split-block method in three replicates (Fig. 1). The plot area was $256 \mathrm{~m}^{2}$ (16 x $16 \mathrm{~m}$ ). Two factors were analysed: two simplified crop rotation systems and three increasing levels of mineral fertilisation within sub-blocks:

- rapeseed and cereal crop rotation - alternate cultivation

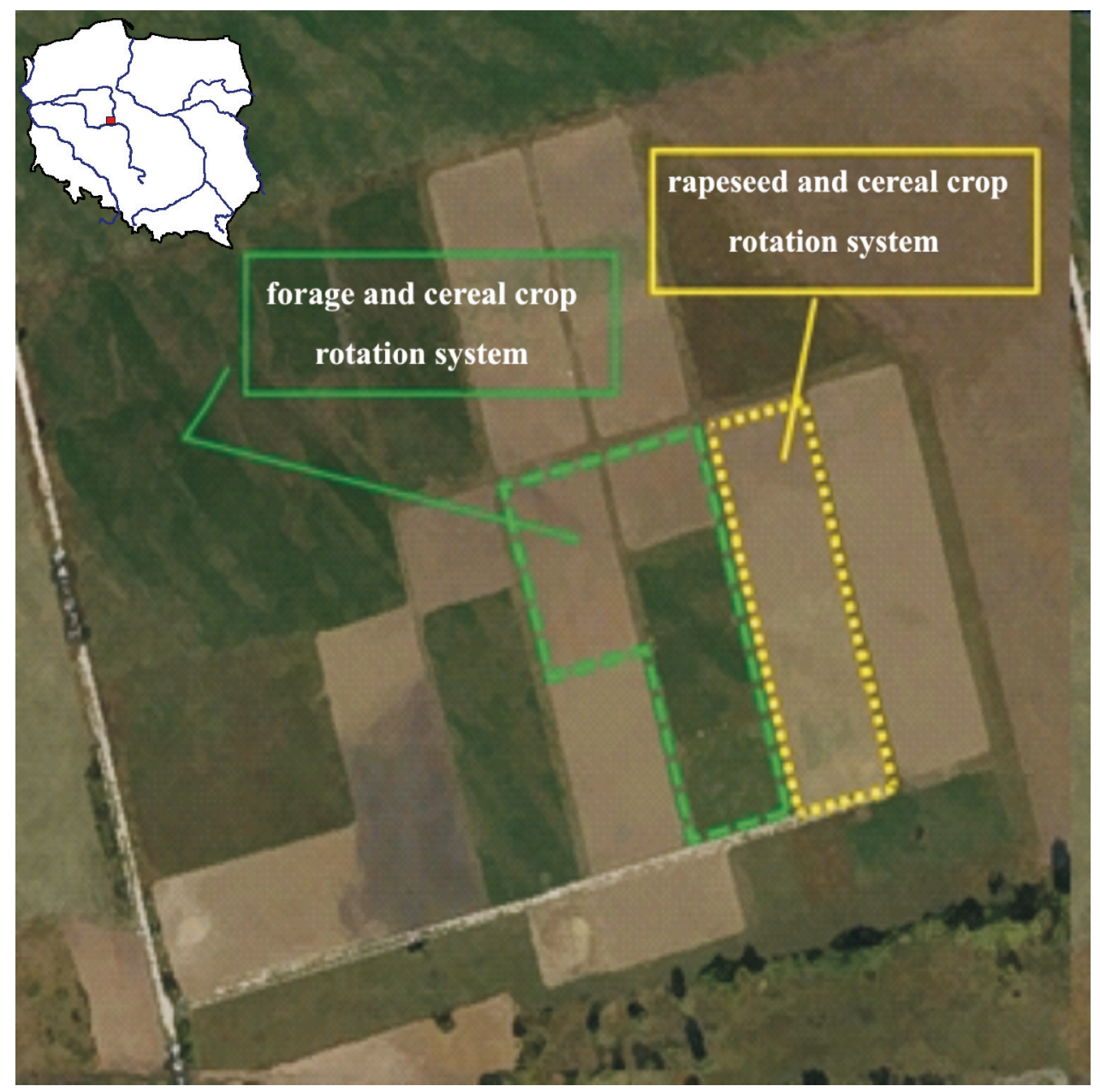

Fig. 1. A view of the research site - satellite image. Source: Google Maps 
Table 1

The mineral fertiliser doses used in the experiment in accordance with combination $1 \mathrm{NPK}$ $\left(\mathrm{kg} \cdot \mathrm{ha}^{-1}\right)$ Source: Spychalski et al. (2005)

\begin{tabular}{lllllll}
\hline Crop species & \multicolumn{2}{l}{$\begin{array}{l}\text { Chemistry repair applied } \\
\text { in first 10 years }\end{array}$} & \multicolumn{3}{l}{$\begin{array}{l}\text { Mineral fertilisation applied } \\
\text { since year 11 till now }\end{array}$} \\
\cline { 2 - 6 } & $\mathrm{N}$ & $\mathrm{P}_{2} \mathrm{O}_{5}$ & $\mathrm{~K}_{2} \mathrm{O}$ & $\mathrm{N}$ & $\mathrm{P}_{2} \mathrm{O}_{5}$ & $\mathrm{~K}_{2} \mathrm{O}$ \\
\hline Winter wheat & 160 & 270 & 140 & 160 & 40 & 80 \\
Winter rapeseed & 200 & 460 & 150 & 200 & 70 & 90 \\
Alfalfa with grasses & 170 & 380 & 260 & 170 & 70 & 150 \\
\hline
\end{tabular}

of winter wheat and winter rapeseed. Mineral fertilisation was applied at three doses: 0NPK, 1NPK, 2NPK. Every year crop residues were ploughed;

- forage and cereal crop rotation - alfalfa and grass were grown for four years to limit the number of agrotechnical treatments favouring soil homogenisation. In the next two years winter wheat was grown and its crop residues were ploughed. Mineral fertilisation was applied in the following combinations: 0NPK, $1 \mathrm{NPK}, 2 \mathrm{NPK}$.

Table 1 shows the amounts of fertilisers used in combination 1NPK. There was no fertilisation in combination 0NPK (the control variant). The amount of the fertiliser used in combination $2 \mathrm{NPK}$ was twice as high as the dose in combination 1NPK. Nitrogen was applied in the form of ammonium nitrate. The fertiliser was applied at dates corresponding to the stages of development of the crops. Phosphorus was applied into the soil in the form of enriched granular superphosphate $40 \% \mathrm{P}_{2} \mathrm{O}_{5}$, whereas potassium was applied in the form of potassium salt $40 \% \mathrm{~K}_{2} \mathrm{O}$.

\subsection{Analytical methods}

Each year in the spring and autumn average soil samples for microbiological analyses were collected with an autosampler from a layer of 0-30 cm, following the rules specified in Polish standard PN-ISO 1998 (Drzymała, 1998). The counts of selected groups of soil microorganisms were measured by means of serial dilution. All measurements were replicated three times. The results were calculated per $1 \mathrm{~g}$ of dry mass of soil and expressed as colony forming units (CFU). The count of soil microorganisms was measured on selective media, using specific dilutions of soil suspensions:

- the total count of heterotrophic bacteria was measured on ready-made Standard-Merck agar; the plates were incubated for 5 days at $25^{\circ} \mathrm{C}$;

- the count of actinobacteria was measured on Pochon agar (Grabińska-Leniowska, 1999) after 5-day incubation at $28^{\circ} \mathrm{C}$;

- the count of moulds was measured on Martin agar (1950) after 10 -day incubation at $28^{\circ} \mathrm{C}$;

- the count of bacteria of the Azotobacter sp. genus was measured on an agar according to the method developed by Fenglerowa (1970) after 5-day incubation at $24^{\circ} \mathrm{C}$.

The activity of the following enzymes was measured in biochemical tests: dehydrogenases - the Thalmann method (Schinner et al., 1995), urease - the Hoffmann and Teicher method (Schinner et al., 1995), alkaline phosphatase - the Tabatabai and Bremner method (Schinner et al., 1995), proteases - the Ladd and Butler method (Schinner et al., 1995).

The results were analysed statistically with one-way analysis of variance. Homogeneous groups were identified by means of Tukey's test at a significance level $\alpha=0.05$. The Statistica 13.1 program was used for statistical calculations. The data sets was also analysed using canonical variate analysis (Lejeune and Caliński, 2000; Kayzer et al., 2009), a form of multivariate analysis, which makes possible a graphical presentation of the results of estimation the similarities between the studied soil microorganisms (or soil enzymes) for the particular crop rotation system. This method, similar to principal component analysis, was chosen because considering data sets coming from the multidimensional experimental structure, it means besides replicates, the other source of variation are taken into consideration, such as crop rotation system type, measuring series and interactions (Kayzer et al., 2018; Kayzer, 2019). Canonical variates were determined with the procedure developed at the Department of Mathematical and Statistical Methods, Poznań University of Life Sciences, Poland.

\section{Results}

According to the Polish Soil Classification (Kabała et al., 2019), the soils analysed in the study were classified as the Technogenic type, Aggerosole subtype. According to WRB (IUSS Working Group WRB, 2015) they were classified as Calcaric Regosols (Loamic, Transportic). The soils were classified as sandy loam of the texture and as medium soils in terms of the agronomic category. The $\mathrm{pH}$ in the $\mathrm{KCl}$ and $\mathrm{H}_{2} \mathrm{O}$ extract was alkaline
Table 2

The mean organic carbon and total nitrogen content in soil

\begin{tabular}{lll}
\hline Crop rotation system & \multicolumn{1}{l}{ TOC } & TN \\
\cline { 2 - 3 } & $\mathrm{g} \cdot \mathrm{kg}^{-1}$ soil \\
\hline Rapeseed and cereal crop rotation system & $6.82^{\mathrm{b}}$ & $0.57^{\mathrm{a}}$ \\
\hline Forage and cereal crop rotation system & $9.43^{\mathrm{a}}$ & $0.88^{\mathrm{b}}$ \\
\hline
\end{tabular}


(7.5-8.5). The average content of organic carbon and total nitrogen is shown in Table 2.

The activity of the soils microorganisms exhibited high variability both in the growing season and in the subsequent years of the research. The total count of heterotrophic bacteria in soil samples collected from the rapeseed and cereal crop rotation system ranged from 11.1 to $91.4 \cdot 10^{5} \mathrm{cfu} \cdot \mathrm{g}^{-1} \mathrm{~d} . \mathrm{m}$. of soil, whereas in the forage and cereal crop rotation system it ranged from 14.1 to $114 \cdot 10^{5} \mathrm{cfu} \cdot \mathrm{g}^{-1} \mathrm{~d} . \mathrm{m}$. of soil (Table 3 ). The analysis of variance of the samples collected from the plots with the rapeseed and cereal crop rotation system did not reveal a statistically significant effect of mineral fertilisation on the count of bacteria. However, the analysis of variance showed that the fertilisation significantly affected the total count of these microorganisms in the soil samples collected from the plots with the forage and cereal crop rotation system. The highest count of the bacteria was found in the soil samples fertilised with the 2NPK dose. The count of bacteria in the soil samples fertilised with the $1 \mathrm{NPK}$ dose did not differ statistically from the count in the samples collected from the non-fertilised 0NPK control variant (Table 3). Apart from that, the crops grown in the plots significantly affected the count of heterotrophic bacteria (Table 4). The statistical analysis showed a significantly greater (about 20\%) count of the bacteria in the soil samples collected from the plots with the forage and cereal crop rotation system (Table 4).

The count of moulds in the soil samples collected from the rapeseed and cereal crop rotation system ranged from 12.4 to $115 \cdot 10^{3} \mathrm{cfu} \cdot \mathrm{g}^{-1} \mathrm{~d} . \mathrm{m}$. of soil (Table 3 ), whereas in the soil samples collected from the plots with the forage and cereal crop rotation system the count of moulds ranged from 24.0 to 95.1 . $10^{3} \mathrm{cfu} \cdot \mathrm{g}^{-1} \mathrm{~d} . \mathrm{m}$. of soil. The analysis of variance clearly showed that the diversified mineral fertilisation of the soils in the rapeseed and cereal crop rotation system significantly affected the count of these microorganisms. The smallest count of moulds was found in the soil samples collected from the unfertilised ONPK control variants. The 1 NPK fertiliser dose did not significantly increase the count of moulds, whereas the 2NPK dose

\section{Table 3}

The range and mean count of soil microorganisms in the soil samples collected from both crop rotation systems depending on the mineral fertilisation combination

\section{Table 4}

The mean count of soil microorganisms in the soil samples collected from both crop rotation systems

\begin{tabular}{|c|c|c|c|c|c|}
\hline \multirow[t]{2}{*}{ Soil microorganisms } & \multirow[t]{2}{*}{$\begin{array}{l}\text { Fertiliser } \\
\text { combination }\end{array}$} & \multicolumn{2}{|c|}{$\begin{array}{l}\text { Rapeseed and cereal crop } \\
\text { rotation system }\end{array}$} & \multicolumn{2}{|c|}{$\begin{array}{l}\text { Forage and cereal crop } \\
\text { rotation system }\end{array}$} \\
\hline & & Range & Mean & Range & Mean \\
\hline \multirow{3}{*}{$\begin{array}{l}\text { Total count of } \\
\text { heterotrophic bacteria } \\
\left(10^{5} \mathrm{cfu} \cdot \mathrm{g}^{-1} \mathrm{~d} . \mathrm{m} \text {. soil }\right)\end{array}$} & ONPK & $14.4-73.7$ & $34.9^{\mathrm{a}}$ & $17.3-76.5$ & $38.2^{\mathrm{a}}$ \\
\hline & $1 \mathrm{NPK}$ & $13.2-91.4$ & $37.4^{\mathrm{a}}$ & $14.1-114$ & $41.7^{\mathrm{a}}$ \\
\hline & $2 \mathrm{NPK}$ & $11.1-87.6$ & $37.0^{\mathrm{a}}$ & $23.8-91.0$ & $50.7^{b}$ \\
\hline \multirow{3}{*}{$\begin{array}{l}\text { Moulds } \\
\left(10^{3} \mathrm{cfu} \cdot \mathrm{g}^{-1} \mathrm{~d} \text {.m. soil) }\right.\end{array}$} & 0NPK & $14.9-42.8$ & $28.8^{a}$ & 23.1-95.1 & $52.7^{\mathrm{a}}$ \\
\hline & $1 \mathrm{NPK}$ & $16.1-72.4$ & $36.2^{\mathrm{a}}$ & $24.0-94.9$ & $56.5^{\mathrm{a}}$ \\
\hline & $2 \mathrm{NPK}$ & $12.4-115$ & $48.8^{\mathrm{b}}$ & $32.2-90.7$ & $58.9^{\mathrm{a}}$ \\
\hline \multirow{3}{*}{$\begin{array}{l}\text { Actinobacteria } \\
\left(10^{4} \mathrm{cfu} \cdot \mathrm{g}^{-1} \mathrm{~d} . \mathrm{m} \text {. soil }\right)\end{array}$} & ONPK & $1.12-158$ & $44.6^{\mathrm{a}}$ & $4.60-215$ & $54.6^{\mathrm{a}}$ \\
\hline & $1 \mathrm{NPK}$ & $1.14-115$ & $31.2^{\mathrm{a}}$ & $2.28-173$ & $52.7^{\mathrm{a}}$ \\
\hline & $2 \mathrm{NPK}$ & $4.31-155$ & $38.8^{\mathrm{a}}$ & $5.60-211$ & $64.6^{\mathrm{a}}$ \\
\hline \multirow{3}{*}{$\begin{array}{l}\text { Azotobacter sp. } \\
\text { (cfu } \cdot \mathrm{g}^{-1} \text { d.m. soil) }\end{array}$} & ONPK & $7.85-93.9$ & $29.4^{\mathrm{a}}$ & $11.5-36.5$ & $20.6^{\mathrm{a}}$ \\
\hline & $1 \mathrm{NPK}$ & $9.80-68.4$ & $23.5^{\mathrm{a}}$ & $11.8-48.5$ & $23.5^{\mathrm{a}}$ \\
\hline & 2NPK & $4.63-78.9$ & $26.4^{\mathrm{a}}$ & $10.8-72.7$ & $28.3^{b}$ \\
\hline
\end{tabular}

The mean values for particular soil microorganisms in each fertiliser combinations marked with the same letter do not differ significantly at $\alpha=0.05$.

\begin{tabular}{lll}
\hline Soil microorganisms & $\begin{array}{l}\text { Rapeseed and cereal } \\
\text { crop rotation system }\end{array}$ & $\begin{array}{l}\text { Forage and cereal crop } \\
\text { rotation system }\end{array}$ \\
\hline $\begin{array}{l}\text { Total count of heterotrophic bacteria } \\
\left(10^{5} \mathrm{cfu} \cdot \mathrm{g}^{-1} \mathrm{~d} \cdot \mathrm{m} \text {. soil }\right)\end{array}$ & $36.4^{\mathrm{a}}$ & $43.5^{\mathrm{b}}$ \\
\hline Moulds $\left(10^{3} \mathrm{cfu} \cdot \mathrm{g}^{-1} \mathrm{~d} \cdot \mathrm{m}\right.$. soil) & $37.9^{\mathrm{a}}$ & $56.0^{\mathrm{b}}$ \\
\hline Actinobacteria $\left(10^{4} \mathrm{cfu} \cdot \mathrm{g}^{-1} \mathrm{~d} \cdot \mathrm{m}\right.$. soil $)$ & $38.2^{\mathrm{a}}$ & $57.6^{\mathrm{b}}$ \\
\hline Azotobacter $\mathrm{sp}$ ( $\left(\mathrm{cfu} \cdot \mathrm{g}^{-1} \mathrm{~d} \cdot \mathrm{m}\right.$. soil) & $26.4^{\mathrm{a}}$ & $24.2^{\mathrm{a}}$ \\
\hline
\end{tabular}

The mean values for particular soil microorganisms marked with the same letter do not differ significantly at $\alpha=0.05$. 
significantly increased their count - by about $34 \%$, as compared with the $1 \mathrm{NPK}$ combination, and by about $70 \%$, as compared with the 0NPK dose. The mineral fertilisation did not have significant effect on the count of moulds in the soil samples collected from the plots with the forage and cereal crop rotation system (Table 3). As was the case with the total count of heterotrophic bacteria, the average count of moulds in the samples collected from the plots with the forage and cereal crop rotation system was significantly greater (about $50 \%$ ) than in the samples collected from the plots with the rapeseed and cereal crop rotation system (Table 4).

The count of actinobacteria in the soil samples collected from the plots with the rapeseed and cereal crop rotation system ranged from 1.12 to $158 \cdot 10^{4}$ $\mathrm{cfu} \cdot \mathrm{g}^{-1} \mathrm{~d}$.m. of soil, whereas in the samples collected from the plots with the forage and cereal crop rotation system it ranged from 2.28 to $215 \cdot 10^{4} \mathrm{cfu} \cdot \mathrm{g}^{-1}$ d.m. of soil (Table 3). The analysis of variance of the samples collected from the plots with the rapeseed and cereal crop rotation system did not reveal a significant effect of mineral fertilisation on the count of actinobacteria. The highest count of these microorganisms was found in the non-fertilised samples (0NPK), whereas the doses of 1 NPK and 2NPK did not have a statistically significant effect on changes in their count (Table 3). The activity of actinobacteria was significantly (about 50\%) higher in the soil samples collected from the plots with the rapeseed and cereal crop rotation system (Table 4).

The count of bacteria of the Azotobacter sp. genus in the soil samples collected from the plots with the rapeseed and cereal crop rotation system ranged from 4.63 to $93.9 \mathrm{cfu} \cdot \mathrm{g}^{-1} \mathrm{~d} . \mathrm{m}$. of soil, whereas in the samples collected from the plots with the forage and cereal crop rotation system it ranged from 10.8 to $72.7 \mathrm{cfu} \cdot \mathrm{g}^{-1} \mathrm{~d} . \mathrm{m}$. of soil (Table 3 ). The analysis of variance showed that diversified mineral fertilisation had no significant influence on changes in the count of Azotobacter sp. bacteria only in the rapeseed and cereal crop rotation system (Table 3). However, the count of Azotobacter sp. bacteria in the forage and cereal crop rotation system was significantly affected by the 2NPK dose of the fertiliser, as compared with the variant fertilised with the $1 \mathrm{NPK}$ dose and the control variant (0NPK). The statistical analysis showed that neither of the crop rotation systems had significant influence on the count of Azotobacter sp. bacteria (Table 4).

The canonical variate analysis (CVA) for the rapeseed and cereal crop rotation system showed that the count of microorganisms under study was mostly affected by the soil sampling term (Fig. 2). This diversity was caused by factors such as moisture, temperature and the phase of development of the plants. The count of heterotrophic bacteria and moulds in the spring was greater than in the autumn. The 2NPK dose of the fertiliser

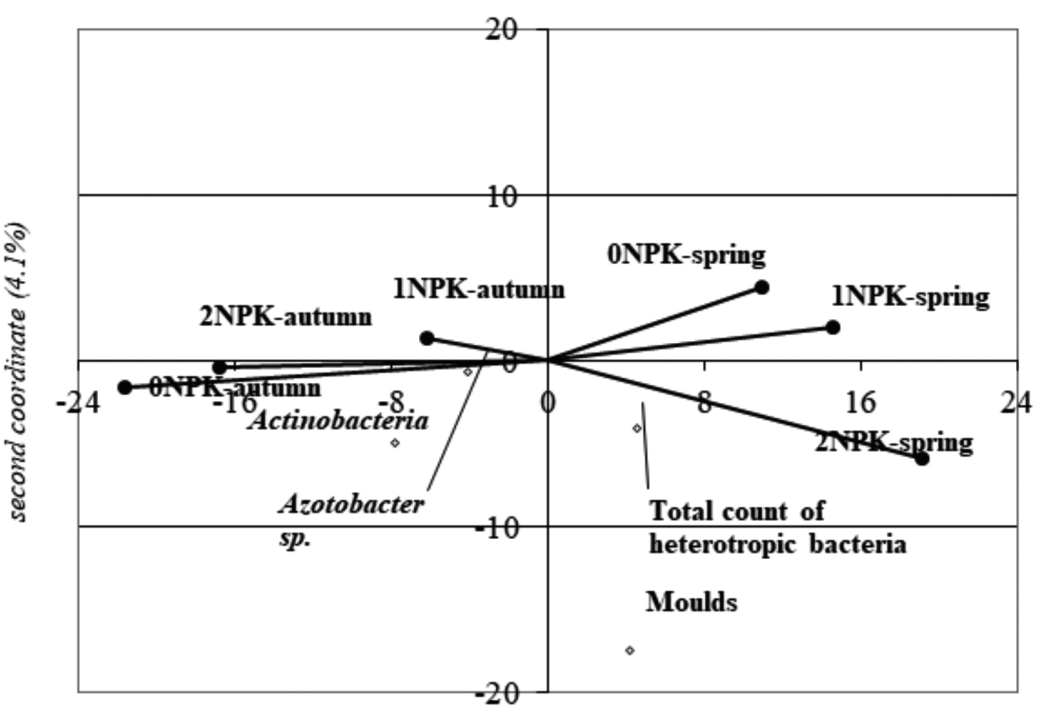

first coordinate (95.5\%)

Fig. 2. The location of the points specifying the applied fertilisation combinations in relation to the count of soil microorganisms in the first two canonical variates for the soil samples collected from the rapeseed and cereal crop rotation system and the position of the count of microorganisms in dual space

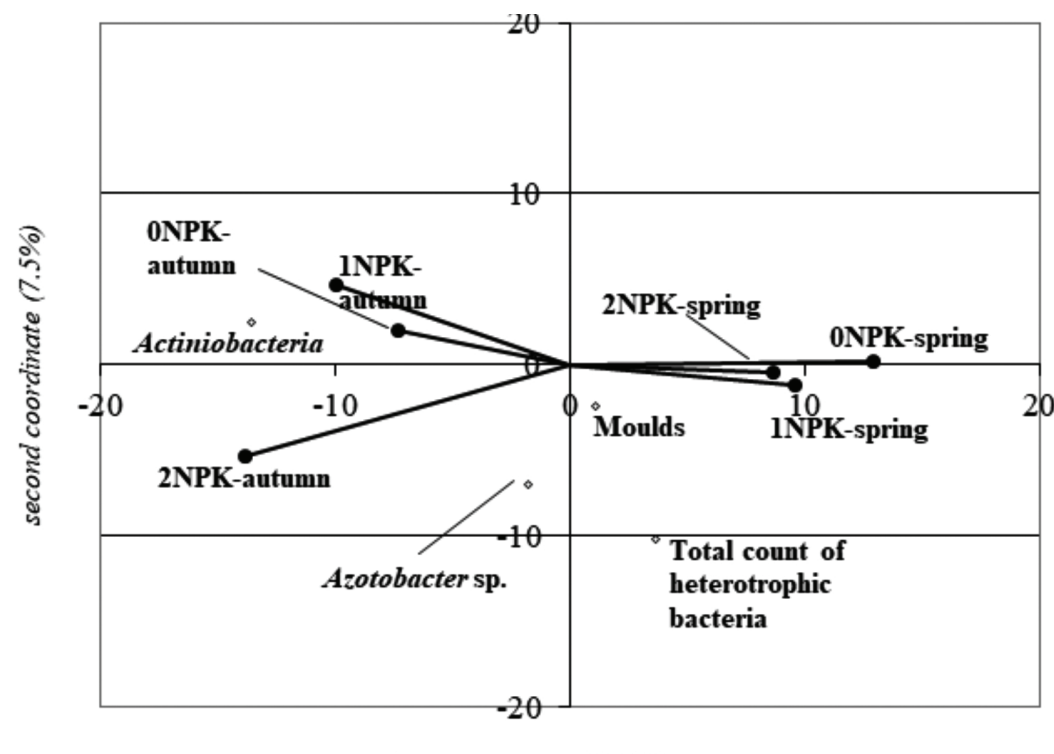

Fig. 3. The location of the points specifying the applied fertilisation combinations in relation to the count of soil microorganisms in the first two canonical variates for the soil samples collected from the forage and cereal crop rotation system and the position of the count of microorganisms in dual space

resulted in the smallest increase in the count of these microorganisms. In the autumn Azotobacteria and actinobacteria were more abundant, and the 0NPK fertilisation (control) variant had the best effect on the count of these microorganisms. The 1NPK fertiliser dose caused a decrease in the counts of actinobacteria and bacteria of the Azotobacter sp. genus.

The CVA results for the forage and cereal crop rotation system suggest that the count of the groups of microorganisms 
under study was influenced by friendly weather conditions during the growing season (Fig. 3). There were greater counts of heterotrophic bacteria and moulds in the soil samples fertilised with the 2NPK dose and collected in the spring. However, the counts of actinobacteria and bacteria of the Azotobacter sp. genus were larger in the autumn. The 2NPK dose of the fertiliser caused the highest increase in the counts of actinobacteria and bacteria of the Azotobacter sp. genus. The growing of alfalfa in this crop rotation system undoubtedly levelled the negative effect of mineral fertilisation on the count of Azotobacter sp. bacteria.

The dehydrogenase activity in the soil samples collected from the rapeseed and cereal crop rotation system ranged from 0.001 to $0.164 \mu \mathrm{mol} \mathrm{TPF} \cdot \mathrm{g}^{-1} \mathrm{~d}$.m. of soil. $24 \mathrm{~h}^{-1}$, whereas in the soil samples collected from the forage and cereal crop rotation system it ranged from 0.006 to $0.265 \mu \mathrm{mol} \mathrm{TPF} \cdot \mathrm{g}^{-1} \mathrm{~d}$.m. of soil $\cdot 24 \mathrm{~h}^{-1}$ (Table 5 ). The analysis of variance showed that the $1 \mathrm{NPK}$ fertiliser dose significantly increased the dehydrogenase activity in the rapeseed and cereal crop rotation system. The 2NPK fertiliser dose did not cause this effect. The mineral fertilisation of the forage and cereal plots did not cause significant changes in the dehydrogenase activity (Table 5). The activity of this enzyme was significantly influenced by the species of crops grown in the plots (Table 6). The dehydrogenase activity in the soil samples collected from the plots with the forage and cereal crop rotation system was significantly higher (almost $100 \%$ ) than in the soil samples collected from the plots with the rapeseed and cereal crop rotation system.

The urease activity in the soil samples collected from the rapeseed and cereal crop rotation system ranged from 0.18 to $3.35 \mu \mathrm{g} \mathrm{N}-\mathrm{NH}_{4} \cdot \mathrm{g}^{-1} \mathrm{~d}$.m. of soil $\cdot 18 \mathrm{~h}^{-1}$, whereas in the soil samples collected from the forage and cereal crop rotation system it ranged from 0.33 to $5.11 \mu \mathrm{g} \mathrm{N}-\mathrm{NH}_{4} \cdot \mathrm{g}^{-1} \mathrm{~d}$.m. of soil $\cdot 18 \mathrm{~h}^{-1}$ (Table 5). The 1 NPK fertiliser dose significantly increased the urease activity in the soil samples collected from the rapeseed and cereal crop rotation system. The $2 \mathrm{NPK}$ fertiliser dose did not

\section{Table 5}

The range and mean enzymes activity in the soil samples collected from both crop rotation systems depending on the mineral fertilisation combination

\section{Table 6}

The mean soil enzymes activity in the soil samples collected from both crop rotation systems

\begin{tabular}{|c|c|c|c|c|c|}
\hline \multirow[t]{2}{*}{ Soil enzymes } & \multirow[t]{2}{*}{$\begin{array}{l}\text { Fertiliser } \\
\text { combination }\end{array}$} & \multicolumn{2}{|c|}{$\begin{array}{l}\text { Rapeseed and cereal } \\
\text { crop rotation system }\end{array}$} & \multicolumn{2}{|c|}{$\begin{array}{l}\text { Forage and cereal crop } \\
\text { rotation system }\end{array}$} \\
\hline & & Range & Mean & Range & Mean \\
\hline \multirow{3}{*}{$\begin{array}{l}\text { Dehydrogenases } \\
\left(\mu \mathrm{mol} \mathrm{TPF} \cdot \mathrm{g}^{-1} \text { d.m. soil } \cdot 24 \mathrm{~h}^{-1}\right)\end{array}$} & ONPK & $0.001-0.067$ & $0.019^{\mathrm{a}}$ & $0.017-0.252$ & $0.074^{\mathrm{a}}$ \\
\hline & $1 \mathrm{NPK}$ & $0.005-0.160$ & $0.045^{b}$ & $0.006-0.265$ & $0.088^{\mathrm{a}}$ \\
\hline & $2 \mathrm{NPK}$ & $0.005-0.164$ & $0.048^{b}$ & $0.013-0.201$ & $0.065^{\mathrm{a}}$ \\
\hline \multirow{3}{*}{$\begin{array}{l}\text { Urease } \\
\left(\mu \mathrm{g} \mathrm{N}-\mathrm{NH}_{4} \cdot \mathrm{g}^{-1} \text { d.m. soil } \cdot 18 \mathrm{~h}^{-1}\right)\end{array}$} & 0NPK & $0.18-3.35$ & $0.59^{\mathrm{a}}$ & $0.79-4.15$ & $2.22^{\mathrm{a}}$ \\
\hline & $1 \mathrm{NPK}$ & $0.62-2.81$ & $1.39^{\mathrm{b}}$ & 0.81-5.11 & $2.29^{\mathrm{a}}$ \\
\hline & $2 \mathrm{NPK}$ & $0.63-3.15$ & $1.49^{\mathrm{b}}$ & $0.33-4.62$ & $2.13^{\mathrm{a}}$ \\
\hline \multirow{3}{*}{$\begin{array}{l}\text { Alkaline phosphatase } \\
\left(\mu \mathrm{mol} \text { PNP.kg-1 d.m. soil } \cdot \mathrm{h}^{-1}\right)\end{array}$} & 0NPK & $0.21-0.88$ & $0.41^{\mathrm{a}}$ & $0.46-2.26$ & $0.93^{\mathrm{a}}$ \\
\hline & $1 \mathrm{NPK}$ & $0.33-1.33$ & $0.66^{\mathrm{b}}$ & $0.39-2.29$ & $0.86^{a}$ \\
\hline & $2 \mathrm{NPK}$ & $0.29-1.31$ & $0.67^{\mathrm{b}}$ & $0.41-2.48$ & $0.94^{\mathrm{a}}$ \\
\hline \multirow{3}{*}{$\begin{array}{l}\text { Protease } \\
\left(\mathrm{mg} \text { tyrosine } \cdot \mathrm{g}^{-1} \mathrm{~d} . \mathrm{m} . \text { soil } \cdot \mathrm{h}^{-1} \text { ) }\right.\end{array}$} & 0NPK & $1.10-8.84$ & $4.13^{\mathrm{a}}$ & $1.56-9.34$ & $4.23^{\mathrm{a}}$ \\
\hline & $1 \mathrm{NPK}$ & $0.39-13.26$ & $5.05^{\mathrm{a}}$ & $1.87-14.1$ & $5.36^{\mathrm{ab}}$ \\
\hline & 2NPK & $1.34-11.6$ & $5.07^{\mathrm{a}}$ & 2.53-13.1 & $5.90^{\mathrm{b}}$ \\
\hline
\end{tabular}

The mean for particular soil enzymes in each fertiliser combinations marked with the same letter do not differ significantly at $\alpha=0.05$.

\begin{tabular}{lll}
\hline Soil enzymes & $\begin{array}{l}\text { Rapeseed and cereal } \\
\text { crop rotation system }\end{array}$ & $\begin{array}{l}\text { Forage and cereal crop } \\
\text { rotation system }\end{array}$ \\
\hline $\begin{array}{l}\text { Dehydrogenases } \\
\left(\mu \mathrm{mol} \mathrm{TPF} \cdot \mathrm{g}^{-1} \mathrm{~d} \cdot \mathrm{m} . \text { soil } \cdot 24 \mathrm{~h}^{-1}\right)\end{array}$ & $0.038^{\mathrm{a}}$ & $0.076^{\mathrm{b}}$ \\
\hline $\begin{array}{l}\text { Urease } \\
\left(\mu \mathrm{g} \mathrm{N}-\mathrm{NH}_{4} \cdot \mathrm{g}^{-1} \mathrm{~d} . \mathrm{m} . \text { soil } \cdot 18 \mathrm{~h}^{-1}\right)\end{array}$ & $1.16^{\mathrm{a}}$ & $2.21^{\mathrm{b}}$ \\
\hline $\begin{array}{l}\text { Alkaline phosphatase } \\
\left(\mu \mathrm{mol} \mathrm{PNP} \cdot \mathrm{kg}^{-1} \mathrm{~d} \cdot \mathrm{m} . \text { soil } \cdot \mathrm{h}^{-1}\right)\end{array}$ & $0.58^{\mathrm{a}}$ & $0.94^{\mathrm{b}}$ \\
\hline $\begin{array}{l}\text { Protease } \\
\left(\mathrm{mg} \text { tyrosine } \cdot \mathrm{g}^{-1} \mathrm{~d} \cdot \mathrm{m} . \text { soil } \cdot \mathrm{h}^{-1}\right)\end{array}$ & $4.75^{\mathrm{a}}$ & $5.17^{\mathrm{a}}$ \\
\hline
\end{tabular}

The mean values for particular soil enzymes marked with the same letter do not differ significantly at $\alpha=0.05$. 
cause this effect. The long-term use of diversified doses of the fertiliser in the soils with the forage and cereal crop rotation system did not cause statistically significant changes in the urease activity (Table 5). However, the statistical analysis showed that the activity of this enzyme was significantly influenced by the crop species. The urease activity was $90 \%$ higher in the plots with the forage and cereal crop rotation system (Table 6).

The alkaline phosphatase activity in the soil samples collected from the rapeseed and cereal crop rotation system ranged from 0.21 to $1.33 \mu \mathrm{mol}$ PNP. $\mathrm{kg}^{-1} \mathrm{~d} . \mathrm{m}$. of soil $\cdot \mathrm{h}^{-1}$ (Table 5). The analysis of variance showed that the $1 \mathrm{NPK}$ fertiliser dose significantly increased the alkaline phosphatase activity in the plots with the rapeseed and cereal crop rotation system. However, the fertilisation did not cause significant differences in the alkaline phosphatase activity in the forage and cereal crop rotation system (Table 5). The activity of this enzyme was significantly influenced by the species of crops grown in the plots. The alkaline phosphatase activity in the soil samples collected from the plots with the forage and cereal crop rotation system was $62 \%$ higher than in the soil samples collected from the rapeseed and cereal crop rotation system (Table 6).

The protease activity in the soil samples collected from the rapeseed and cereal crop rotation system ranged from 0.39 to $13.26 \mathrm{mg}$ of tyrosine $\cdot \mathrm{g}^{-1}$ d.m. of soil $\cdot \mathrm{h}^{-1}$, whereas in the soil samples collected from the forage and cereal crop rotation system it ranged from 1.56 to $14.1 \mathrm{mg}$ of tyrosine $\cdot \mathrm{g}^{-1} \mathrm{~d} . \mathrm{m}$. of soil $\cdot \mathrm{h}^{-1}$ (Table 5 ). The fertilisation of the soil under the rapeseed and cereal crop rotation system did not cause a statistically significant effect. By contrast, the protease activity in the soil samples collected from the forage and cereal crop rotation system was quite diversified (Table 5). However, the analysis of variance for the protease activity in the soil samples did not show a significant effect of the species of crops grown (Table 6).

The results of the canonical variate analyses (CVA) for the enzymatic activity presented in dual space for the soil samples collected from the plots with the rapeseed and cereal crop rotation system are shown in Fig. 4. There were slight statistical differences in the enzyme activities in the soil samples fertilised with the 1NPK and 2NPK doses both in the spring and autumn. The samples collected from the plots fertilised with the 2 NPK and 1 NPK doses were characterised by the highest dehydrogenase, alkaline phosphatase and protease activities. The highest urease activity was observed in the autumn in the soil samples collected from the plots fertilised with the 1 NPK and 2 NPK doses. As far as the soil samples collected from the forage and cereal crop rotation system are concerned, the CVA showed that after applying different doses

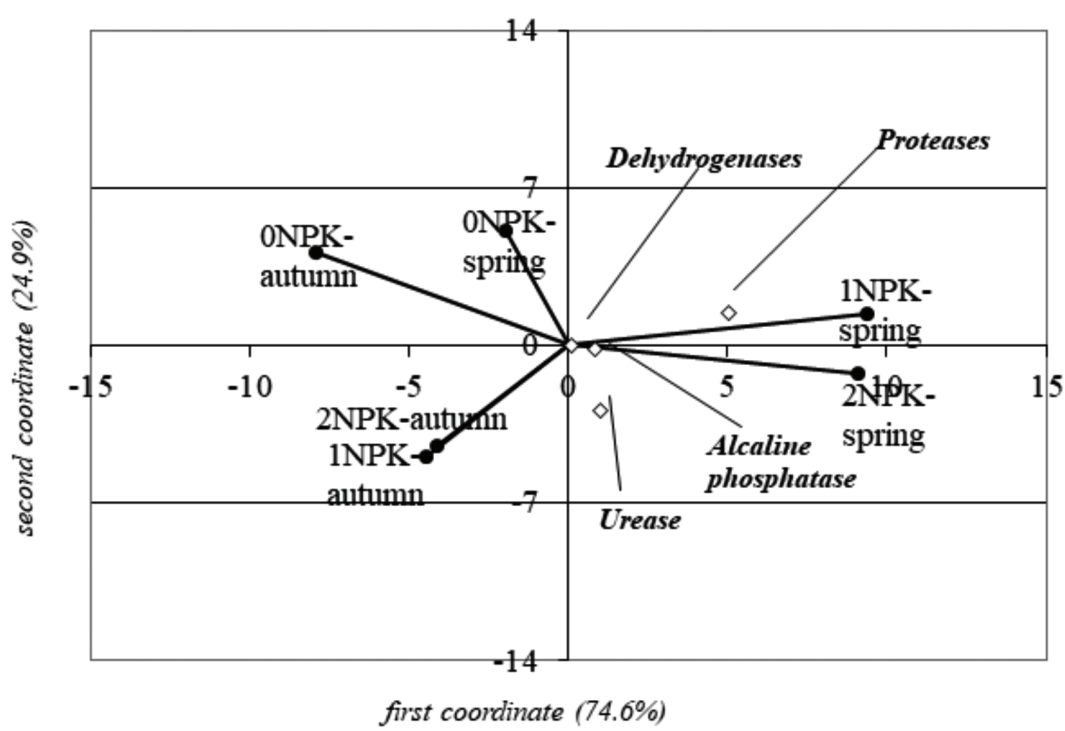

Fig. 4. The location of the points specifying the applied fertilisation combinations in relation to the activity of soil enzymes in the first two canonical variates for the soil samples collected from the rapeseed and cereal crop rotation system and the position of the enzymes in dual space

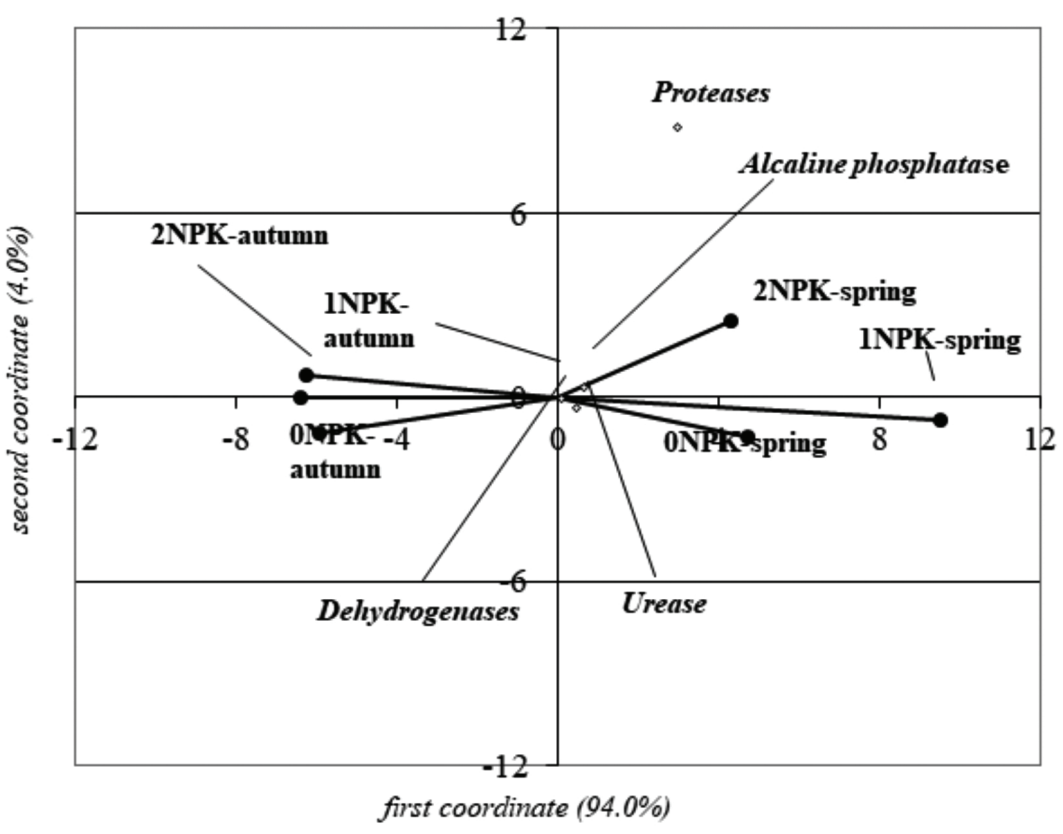

Fig. 5. The location of the points specifying the applied fertilisation combinations in relation to the activity of soil enzymes in the first two canonical variates for the soil samples collected from the forage and cereal crop rotation system and the position of the enzymes in dual space

of the fertiliser the activity of all the enzymes in the spring was relatively high, as compared with the enzymatic activity in the autumn (Fig. 5). However, the results showed that the enzymatic activity in the samples collected in the spring was characterised by greater diversity than in the samples collected in the autumn. The 1NPK dose resulted in the highest dehydrogenase and urease activity, whereas the 2NPK dose resulted in the highest alkaline phosphatase and protease activity. The 
2NPK dose resulted in the lowest dehydrogenase and urease activity in the soil samples collected from the fertilised plots in the autumn. The lowest protease activity was observed in the non-fertilised soil samples (0NPK).

\section{Discussion}

The research results showed that the total count of heterotrophic bacteria was significantly influenced by the soil sampling term, the species of crops grown in the plots, and the applied dose of mineral fertiliser. The 2NPK dose of the fertiliser increased the total count of heterotrophic bacteria, especially in the forage and cereal crop rotation system. Natywa et al. (2010) conducted research on arable soils and also observed high variability in the count of bacteria during the growing season. Jodełka et al. (2011) found that the total count of bacteria decreased when the soil was fertilised with too high doses of nitrogen. Apart from the positive effects of fertilisers available on the market, they often have negative influence on the ecological balance. Homeostasis becomes disturbed and compounds such as hydroxylamines, nitrites, nitrates, and nitrosamines are formed. These compounds have mutagenic, carcinogenic and teratogenic effects on humans, animals and soil microorganisms (Niewiadomska et al., 2010). The soil samples collected in the spring contained more heterotrophic bacteria than those collected in the autumn. This effect may have been caused by lower content of moulds and actinobacteria. The diverse dynamics of changes in the microbiota during the growing season was reported by Furczak and Turska (2006), who observed the highest soil microbiological activity in the spring.

The results of our research also showed that the count of actinobacteria was significantly affected by the species of crops grown in the plots and the soil sampling terms. The count of actinobacteria in the soil samples from the forage and cereal crop rotation system was much larger than in the samples collected from the rapeseed and cereal crop rotation system. This may have been caused by higher content of organic matter in the soil with the forage and cereal crop rotation system. According to Skwaryło-Badnarz (2008) and Sosnowski and Jankowski (2013), vegetation significantly affects the count of these microorganisms. The dynamic development of microorganisms in the root zone is caused by the abundance of easily accessible substance providing energy. During the growth of plants their roots produce organic and inorganic compounds as well as active substances, which favour the growth of actinobacteria (Vogeler et al., 2008; Yang et al., 2008). This observation was confirmed in our study, where the count of actinobacteria in the samples collected in the autumn was greater than in the ones collected in the spring. This may have been caused by interactions between microorganisms, as a result of which bacteria displaced actinobacteria in the spring, but in the autumn actinobacteria dominated the soil populations. Galus-Barchan and Paśmionka (2014) came to similar conclusions based on their research. According to Barabasz and Vořiŝek (2002), high doses of nitrogen $(200 \mathrm{~kg} / \mathrm{ha})$ also stimulated the development of actinobacteria in the soil.
The increase in the count of moulds in the soil samples was significantly influenced by the 2NPK fertiliser dose applied in the rapeseed and cereal crop rotation system. Jodełka et al. (2008, 2011) also observed intense development of moulds at higher doses of the nitrogen fertiliser. Kucharski and Wałdowska (2001) also found that there were more moulds than bacteria when mineral fertilisation was applied. However, this effect was not observed in the forage and cereal crop rotation system. Nevertheless, regardless of the fertiliser dose, the amounts of moulds in all the soil samples collected from the forage and cereal crop rotation system were greater than in the samples collected from the rapeseed and cereal crop rotation system. The extensive root system of alfalfa in the forage and cereal crop rotation system turned out to provide excellent drainage, which enabled adequate oxygenation of the soil and provided additional nutrients. Sosnowski and Jankowski (2013) made similar observations in their study. They found the most moulds in the soils where a mixture of Festulolium braunii plants with clover and alfalfa was grown. The sample collection term significantly affected the count of moulds only in the rapeseed and cereal crop rotation system, where the most moulds were found in the spring. The weather conditions may also have affected the growth of moulds in this period. The sample collection term did not have significant influence on the population of moulds in the forage and cereal crop rotation system. This effect could be accounted for by the fact that alfalfa developed an even root system throughout the growing season, which resulted in high microbial activity.

The research results showed that the mineral fertilisation did not significantly affect the count of Azotobacter bacteria in the soil samples collected from the rapeseed and cereal crop rotation system. There were similar findings of the research conducted by Natywa et al. (2013), who observed that when the fertiliser dose exceeded $80 \mathrm{~kg} \mathrm{~N} \cdot \mathrm{ha}^{-1}$, the count of this group of bacteria decreased. Starzyk et al. (2013) observed that NPK fertilisation caused intensive development of bacteria of the Azotobacter sp genus in soil. In our study the crop rotation system did not have significant effect on changes in the count of Azotobacter bacteria. Only the soil sample collection term significantly influenced the count of these bacteria. There were larger amounts of Azotobacter in the autumn, probably due to the weather conditions. Apart from that, the research showed that the count of these bacteria varied in the subsequent years. The largest population of Azotobacter bacteria was observed in the third year of analyses, when the rainfall was higher than in the entire growing season. Natywa et al. (2013) also proved that the occurrence of these bacteria was influenced by soil moisture. The authors found that the bacterial populations in sprinkled sites were larger than in non-sprinkled ones, regardless of the development phase of plants.

The dehydrogenase activity was affected by the following factors: the fertiliser dose, crop rotation system, the air and water conditions in the soil, especially the sample collection term. The research results confirmed the beneficial effect of mineral fertilisation on the dehydrogenase activity, especially in the soils with the rapeseed and cereal crop rotation system, where the 1 NPK fertiliser dose significantly increased the organic car- 
bon content. As a result, the dehydrogenase activity increased. Many authors (Ciarkowska and Gambuś, 2004; De Mora et al., 2005; Tripathi et al., 2007; Koper et al., 2008; Xiang et al., 2008; Bielińska and Mocek, 2009; Mocek-Płóciniak, 2010; Bielińska et al., 2014; Błońska et al., 2017; Mocek-Płóciniak, 2018) observed that the activity of this group of enzymes depended on the content of organic compounds in soil. These authors also found that the dehydrogenase activity in soils used as pastures was higher than in arable lands. However, in our study the highest dehydrogenase activity was observed in the soils with the forage and cereal crop rotation system, where alfalfa was the main crop. Niewiadomska et al. (2010) also observed that the activity of oxidoreductases was significantly influenced by fertilisation, the type of plants grown and the depth of the root system. The soil sample collection term also significantly affected the dehydrogenase activity, which was higher in the spring. As results from reference publications (Bielińska, 2001; Furczak and Turska, 2006; Bielińska et al., 2014), in the spring enzymes are particularly active, in the summer their activity decreases, and in the autumn they become more active again. Successive seasons of the year cause considerable differences in the soil temperature, and its fluctuations significantly influence enzymatic processes.

The urease activity in the soils with the forage and cereal crop rotation system was higher than in the soils with the rapeseed and cereal crop rotation system. This effect can be accounted for by the higher humus content in the forage and cereal crop rotation system and the presence of alfalfa - a legume with an extensive root system. The fertilisation at a dose of $1 \mathrm{NPK}$ in the plots with the rapeseed and cereal crop rotation system caused a significant increase in the urease activity. However, when the fertiliser dose was increased even more, it did not have a statistically significant effect on the activity of this enzyme. Yang et al. (2008), Zhao et al. (2009) and Symanowicz et al. (2014) also observed that mineral fertilisation significantly influenced variation in the urease activity. In our study the soil sampling term did not have significant effect on the urease activity in either of the crop rotation systems.

The alkaline phosphatase activity depended on the crop rotation system and the fertiliser dose. The long-term fertilisation at a dose of $1 \mathrm{NPK}$ caused a significant increase in the activity of this enzyme in the rapeseed and cereal crop rotation system. The fertilisation may have increased the available organic matter content. According to reference publications, the phosphatase activity is closely related with the content of organic matter (Bielińska, 2001; Bielińska and Mocek-Płóciniak, 2009; Mocek-Płóciniak, 2010; Bielińska et al., 2014; Mocek-Płóciniak, 2018). According to Bielińska (2005), the phosphatase activity does not always reflect the amount of nutrients brought with the mineral fertiliser to the environment. According to Kucharski (1997), mineral fertilisation may also negatively affect the alkaline phosphatase activity. Average doses of mineral fertilisers may stimulate the phosphatase activity, but high doses may reduce the activity of these enzymes in the soil environment (Bielińska and Mocek-Płóciniak, 2009). In our study the highest alkaline phosphatase activity was observed in the forage and cereal crop rotation system fertilised with the 2 NPK dose. The average values in our research were similar to those presented by Lemanowicz and Kopera (2010). Gilewska and Płóciniczak (2007) found high alkaline phosphatase activity in the control plot, where no fertiliser had been used (0NPK). According to the authors, the transformations of organic phosphorus bonds, reflected by the alkaline phosphatase activity, were the most dynamic in the forage and cereal crop rotation system based on alfalfa. In our study the mineral fertiliser dose did not significantly affect the activity of this enzyme in the soil samples collected from the plots with the forage and cereal crop rotation system. This effect can be accounted for by the lack of significant differences in the content of organic carbon in these soils. However, the alkaline phosphatase activity in the soil samples collected from the forage and cereal crop rotation system was almost twice as high as in the rapeseed and cereal crop rotation system due to the extensive root system of alfalfa (Bielińska and Mocek-Płóciniak, 2009). The alkaline phosphatase activity in the soil samples collected in the spring was higher than in the samples collected in the autumn, regardless of the crop rotation system. Koper and Piotrowska (1996) and Mocek-Płóciniak (2010) observed that the phosphomonoesterase activity may depend on periodic variation in the soil temperature and humidity. These authors also observed the maximum phosphatase activity in the spring. Adequate soil moisture is a basic determinant of the activity of soil enzymes. The lowest alkaline phosphatase activity in both crop rotation systems was observed in the first year of the study. According to Bielińska and Mocek-Płóciniak (2009), such fluctuations mostly result from varied weather conditions and very high sensitivity of phosphatases to changes in the soil moisture, temperature and oxygenation. Some authors (Koper and Piotrowska, 1999; Krämer and Green, 2000; Bielińska and Mocek-Płóciniak, 2009) observed high annual fluctuations in the phosphatase activity, whereas others observed small fluctuations (Bielińska, 2001). Apart from that, short-term fluctuations in the count and biomass of microorganisms, small inflow of fresh organic matter and the leaching of enzymes from soil may indicate low phosphatase activity.

The protease activity increased significantly when the 2NPK fertiliser dose was applied to the soils with the forage and cereal crop rotation system. According to Baran (2000), this effect may indicate that organic nitrogen bonds were mineralised more rapidly at this site. The applied mineral fertiliser doses did not have significant influence on the protease activity in the rapeseed and cereal crop rotation system. Also, the proteolytic activity was not significantly influenced by the crop rotation system (crops). The protease activity in the samples collected from both crop rotation systems in the spring was on average almost twice as high as in those collected in the autumn. The highest protease activity was noted in the second year of the research. It may have been caused by better weather conditions at the time of soil sampling, i.e. the soil moisture and oxygenation.

Despite long-term rehabilitation of post-mining soils their microbiological and biochemical parameters are much lower than those of the soils that have been cultivated for hundreds of years (Martyniuk, 2017). The low enzymatic activity in the 
soils analysed in our research shows that the basic groups of microorganisms exhibited limited ability to act in this environment due to the initial phase of biological balance formation in post-mining soils. The variation in the count of individual groups of microorganisms observed during the study was caused by their sensitivity to the current conditions of existence in the specific environment of post-mining soils. According to Badura (2006), less resistant populations are displaced by more resistant ones and they gradually adapt to edaphic conditions.

\section{Conclusions}

1. The microbiological activity of the soils analysed in the study was characterised by high variability both in the growing season and in the subsequent years of the research.

2. The soil samples collected from both crop rotation systems in the spring were characterised by higher activity of dehydrogenases, alkaline phosphatase and proteases. There was slightly higher urease activity observed only in the forage and cereal crop rotation system. In the spring there were greater total counts of heterotrophic bacteria and moulds, whereas in the autumn there were greater counts of actinobacteria and bacteria of the Azotobacter sp. genus.

3. The forage and cereal crop rotation system, in which alfalfa was the main crop, proved to be more beneficial for the count of soil microorganisms and enzymatic activity. Therefore, feed and cereal crop rotation is recommended for the reclamation of soils in internal post-mining dumps, because it improves their biological properties.

\section{References}

Badura, L., 2006. Rozważania nad rolą mikroorganizmów w glebie. (Consideration of role of microorganisms in soil). Zeszyty Naukowe Uniwersytetu Wrocławskiego 89(546), 13-23.

Barabasz, W., Vořišek, K., 2002. Bioróżnorodność mikroorganizmów $\mathrm{w}$ środowiskach glebowych. (Biodiversity of microorganisms in soil environments). [In]: Aktywność drobnoustrojów w różnych środowiskach. Red. W. Barabasz. Wydawnictwo Akademii Rolniczej w Krakowie, 26-27.

Baran, S., 2000. Ocena stanu degradacji i rekultywacji gleb. (Assessment of soil degradation and reclamation). Przewodnik do ćwiczeń. Wydawnictwo Akademii Rolniczej w Lublinie.

Bender, J., Gilewska, M., 2004. Rekultywacja w świetle badań i wdrożeń. (Reclamation in the light of investigations and implementation). Roczniki Gleboznawcze - Soil Science Annual 55(2), 29-46.

Bielińska, E.J., 2001. Aktywność enzymatyczna gleby w sadzie wiśniowym w zależności od metody jej pielęgnacji. (The effect of the soil care method on its enzymatic activity in a cherry orchard). Rozprawy Naukowe 251, Akademia Rolnicza w Lublinie, 251.

Bielińska, E.J., Węgorek, T., Głowacka, A., 2000a. Zmiany aktywności enzymatycznej utworów ilastych na zalesionym zwałowisku kopalni siarki. (Changes in the enzymatic activity of clay formations in an afforested sulphur mine spoil tip). Roczniki Akademii Rolniczej im. Augusta Cieszkowskiego w Poznaniu 317(56), 401-410.

Bielińska, E.J., Baran, S., Domżał, H., 2000b. Zastosowanie wskaźników enzymatycznych do oceny wpływu rocznych zabiegów agrotech- nicznych na poprawę właściwości gleby lekkiej. (The use of enzymatic indicators to assess the influence of annual agrotechnical treatments on the improvement of properties of light soil). Folia Universitatis Agriculturae Stetinensis 211(84), 35-40.

Bielińska, E.J., Węgorek, T., Ligęza, S., Futa, B., 2004. Aktywność enzymatyczna piaskowych industrioziemów zalesionych robinią akacjową (Robinia pseudoacacia L.) zależnie od wystawy stoku zwałowiska (Enzymatic acivity of sandy anthrosols afforested with blacklocust (Robinia pseudoacacia L.) depending on slope exposure of the dumping ground). Roczniki Gleboznawcze - Soil Science Annual 55(2), 69-75.

Bielińska, E.J., 2005. Ocena stanu środowiska glebowego ogrodów działkowych z terenów o różnym oddziaływaniu antropopresji poprzez badanie aktywności fosfataz (An assessment of the condition of the soil environment in allotment gardens in areas with different influence of human pressure by testing the phosphatase activity). Zeszyty Problemowe Postępów Nauk Rolniczych 505, 51-58.

Bielińska, E.J., Mocek-Płóciniak, A., 2009. Fosfatazy w środowisku glebowym. (Phosphatases in the soil environment). Monografia naukowa. Poznań, Wydawnictwo Uniwersytetu Przyrodniczego w Poznaniu.

Bielińska, E.J., Futa, B., Mocek-Płóciniak, A., 2014. Enzymy glebowe jako bioindykatory jakości i zdrowotności gleby. (Soil enzymes as bioindicators of soil quality and health). Monografia naukowa. Lublin, Wydawnictwo Libropolis.

Błońska, E., Lasota, J., Zwydak, M., 2017. Relacje pomiędzy aktywnością enzymatyczną a właściwościami gleb i sposobem użytkowania. (The relationship between soil properties, enzyme activity and land use). Leśne Prace Badawcze 78(1), 39-44. https://doi.org/10.1515/frp2017-0004

Ciarkowska, K., Gambuś, F., 2004. Aktywność dehydrogenaz w glebach zanieczyszczonych metalami ciężkimi w rejonie olkusza. (The dehydrogenase activity in soils contaminated by heavy metals in the area of Olkusz). Zeszyty Problemowe Postępów Nauk Rolniczych 501, 79-85.

De Mora, A.P., Ortega-Calvo, J.J., Cabrera, F., Madejon, E., 2005. Changes in enzyme activities and microbial biomass after "in situ" remediation of a heavy metal - contaminated soil. Applied Soil Ecology 28(2), 125-137. https://doi.org/10.1016/j.apsoil.2004.07.006

Drzymała, S., 1998. Zasady pobierania i przygotowania próbek glebowych do badań mikrobiologicznych. (The rules for collecting and preparing soil samples for microbiological tests). [W:] Ekologiczne aspekty mikrobiologii gleby. Katedra Mikrobiologii Rolnej Akademii Rolniczej im. Augusta Cieszkowskiego w Poznaniu, 65-71.

Fenglerowa, W., 1970. Simple method for counting Azotobacter in soil samples. Acta Microbiologica Polonica 14(2), 203-206.

Furczak, J., Turska, B., 2006. Wpływ różnych systemów uprawy soi na rozwój mikroorganizmów i zawartość fenoli w glebie płowej. (Influence of different soybean cultivation systems on development of microorganisms and phenols content in loess soil). Acta Agrophysica 8(1), 59-68.

Galus-Barchan, A., Paśmionka, I., 2014. Występowanie wybranych mikroorganizmów w glebie na obszarze Puszczy Niepołomickiej ze szczególnym uwzględnieniem grzybów pleśniowych. (The occurrence of selected microorganisms in the soil under forest with particular reference to mould fungi). Polish Journal of Agronomy 17, 11-17.

Gilewska, M., 1991. Rekultywacja gruntów pogórniczych na przykładzie KWB "Konin". (The reclamation of post-mining land. A Case Study of Brown Coal Mine "Konin”). Roczniki Akademii Rolniczej im. Augusta Cieszkowskiego w Poznaniu. Rozprawy Naukowe 211.

Gilewska, M., Płóciniczak, A., 2004. Aktywność enzymatyczna gleb powstających z gruntów pogórniczych. (Enzymatic activity of soils originating from post mining soils). Roczniki Gleboznawcze - Soil Science Annual 55(2), 123-129.

Gilewska, M., Płóciniczak, A., 2007. Aktywność fosfatazy zasadowej w glebach rozwijających się z gruntów pogórniczych. (The alkaline 
phosphatase activity in soils orginating from post mining grounds). Oficyna Wydawnictwa Uniwersytetu Zielonogórskiego, Zeszyty Naukowe 133(13), 116-122.

Grabińska-Leniowska, A., 1999. Laboratory exercises in general microbiology. Warsaw Technical University, 233.

IUSS Working Group WRB, 2015. World Reference Base for soil resources 2014. International soil classification system for naming soils and creating legends for soil maps. Update 2015. World Soil Resources Report, No. 106. FAO, Rome.

Jodełka, J., Jankowski, K., Jakubczak, A., 2008. Sezonowe zmiany liczebności drobnoustrojów w strefie ryzosferowej łąki nawożonej doglebowo i dolistnie. (Seasonal changing of the microorganisms in the rhizosphere level of the meadow fertilized to the soil or as foliar). Łakarstwo w Polsce 11, 67-76.

Jodełka, J., Jankowski, K., Sosnowski, J., 2011. Effect of nitrogen fertilization on microbial properties of meadow soil. Romanian Agricultural Research 28, 181-186.

Kabała, C., et al., 2019. Polish Soil Classification, $6^{\text {th }}$ edition - principles, classification scheme and correlations. Soil Science Annual 70(2), 71-97. https://doi.org/10.2478/ssa-2019-0009

Karczewska, A., 2008. Ochrona gleb i rekultywacja terenów zdegradowanych. (Soil protection and land reclamation in degraded areas). Wydawnictwo Uniwersytetu Przyrodniczego we Wrocławiu.

Kayzer, D., Borowiak, K., Budka, A., Zbierska, J., 2009. Study of interaction in bioindication research on tobacco plant injuries caused by ground level ozone. Environmetrics 20, 666-675. https://doi. org/10.1002/env.970

Kayzer, D., Frankowski, P., Zbierska, J., Staniszewski, R., 2018. Evaluation of trophic parameters in newly built reservoir using canonical variates analysis. [In:] Zielinski, W., Kuchar, L., Michalski, A., Kazmierczak, B., (ed.), XLVIII Seminar of Applied Mathematics, Book Series: ITM Web of Conferences 23, UNSP 00019, 1-6. https:// doi.org/10.1051/itmconf/20182300019

Kayzer, D., 2019. A note on testing hypothesis concerning interaction with special references to graphical presentation in space of canonical variates. Biometrical Letters 56(1), 89-104. https://doi. org/10.2478/bile-2019-0008

Koper, J., Piotrowska, A., 1996. Aktywność enzymatyczna gleby płowej w zależności od uprawy roślin w zmianowaniu i monokulturze. (Enzymatic activity of lessive soil as effect of plant cultivated in monoculture and in crop rotation). Roczniki Gleboznawcze - Soil Science Annual 47(3/4), 89-100.

Koper, J., Piotrowska, A., 1999. Aktywność enzymatyczna gleby jako parametr jej żyzności wywołany systemem uprawy. (Soil enzymatic activity as a factor of its fertility caused by the tillage system). Zeszyty Problemowe Postępów Nauk Rolniczych 467(1), 127-134.

Koper, J., Piotrowska, A., Siwik-Ziomek, A., 2008. Aktywność dehydrogenaz i inwertazy w glebie rdzawej leśnej w okolicy zakładów azotowych Anwil we Włocławku. (Dehydrogenase and invertase activities in a rusty soil in the neighbourhood of the Włocławek nitrogen plant „Anwil”). Wydawnictwo Anwil Włocławek [In:] Proceedings of ECOpole 2(1), 197-202.

Krămer, S., Green, D.M., 2000. Acid and alkaline phosphatase dynamics and their relationship to soil microclimate in a semiarid woodland. Soil Biology and Biochemistry 32(2), 179-188. https://doi. org/10.1016/S0038-0717(99)00140-6

Kucharski, J., 1997. Relacje między aktywnością drobnoustrojów a żyznością gleby. (The relations between microbial activity and soil fertility). [W:] Drobnoustroje w środowisku. Występowanie, aktywność i znaczenie. Praca zbiorowa. Red. W. Barabasz. Akademia Rolnicza w Krakowie, 327-347.

Kucharski, J., Wałdowska, E., 2001. Mikrobiologiczne skutki wieloletniego nawożenia gnojowicą. (The microbiological effects of long-term fertilisation with liquid manure). Zeszyty Problemowe Postępów Nauk Rolniczych 476, 205-210.
Lejeune, M., Caliński, T., 2000. Canonical analysis applied to multivariate analysis of variance. Journal of Multivariate Analysis 72(1), 100-119. https://doi.org/10.1006/jmva.1999.1852

Lemanowicz, J., Koper, J., 2010. Changes of available content and soil phosphatases activity in result of mineral fertilisation. Soil Science Annual 61(4), 140-145.

Marinari, S., Mancinelli, R., Campiglia, E., Grego, S., 2006. Chemical and biological indicators of soil quality in organic and conventional farming systems in Italy. Ecological Indicators 6(4), 701-711. https:// doi.org/10.1016/j.ecolind.2005.08.029

Martin, J.P., 1950. Use of acid, rose bengal and streptomycin in the plate method for estimating soil fungi. Soil Science 69, 215-232. https:// dx.doi.org/101097/00010694-195003000-00006

Martyniuk, S., 2017. Żyzna gleba. (Fertile soil). Farmer 4, 116-120.

Mocek-Płóciniak, A., 2010. Wykorzystanie aktywności enzymatycznej do oceny wpływu antropogenicznych zmian wywołanych przez metale ciężkie w środowisku glebowym. (Utilisation of enzymatic activity for the evaluation of the impact of anthropogenic changes caused by heavy metals in soil environment). Nauka Przyroda Technologie 4(6), \#86.

Mocek-Płóciniak, A., 2018. Właściwości fizyczno-chemiczne oraz mikrobiologiczne gleb kształtujących się na składowisku popiołów i żużli elektrownianych. (The physicochemical and microbiological properties of soils developing in landfills with ash and slag from power plants). Uniwersytet Przyrodniczy w Poznaniu. Rozprawy naukowe 499, 180.

Natywa, M., Sawicka, A., Wolna-Maruwka, A., 2010. Aktywność mikrobiologiczna i enzymatyczna gleby pod uprawą kukurydzy w zależności od zróżnicowanego nawożenia azotem. (Microbial and enzymatic activity in the soil under maize crop in relation to differentiated nitrogen fertilisation). Woda-Środowisko-Obszary Wiejskie 10(2), 111-120.

Natywa, M., Selwet, M., Ambroży, K., Pociejowska, M., 2013. Wpływ nawożenia azotem i deszczowania na liczebność bakterii z rodzaju Azotobacter w glebie pod uprawą kukurydzy w różnych fazach rozwoju rośliny. (The effect of nitrogen fertilization and irrigation on the number of Azotobacter in the soil under maize at different stages of plant development). Polish Journal of Agronomy 14, 53-58.

Niewiadomska, A., Kleiber, T., Klama, J., Swędrzyńska, D., 2010. Wpływ zróżnicowanego nawożenia azotowego na dynamikę składu mikrobiologicznego gleby i aktywność enzymatyczną dehydrogenaz pod trawnikiem. (The effect of varied nitrogen fertilization on dynamics of soil microbiological composition and enzymatic activity of dehydrogenases under lawns). Nauka Przyroda Technologie 4(6), \#90.

Podgaiski, L.R., Rodrigues, G.G., 2010. Leaf-litter decomposition of pioneer plants and detritivore macrfaunal assemblages on coal ash disposals in southern Brazil. European Journal of Soil Biology 46, 394-400. http://doi.org/10.1016/j.ejsobi2010.09.001

Saarsalmi, A., Smolander, A., Kukkola, M., Moilanem, M., Saramaki, J., 2012. 30-Year effects of wood ash and nitrogen fertilization on soil chemical properties, soil microbial processes and stand growth in a Scots pine stand. Forest Ecology and Management 278, 63-70. https://doi.org/10.1016/j.foreco.2012.05.006

Schinner, F., Ohlinger, R., Kandeler, E., Margesin, R., 1995. Methods in Soil Biology. Springer Verlag-Berlin Heidelberg.

Schmidt, A., Haferburg, G., Sineriz, D.M., Buchel, G., Kothe, E., 2005. Heavy metal resistance mechanisms an actinobacteria for survival in AMD contaminated soils. Chemie der Erde 65, 131-144. https:// doi.org/10.1016/j.chemer.2005.06.006

Skwaryło-Bednarz, B., 2008. Ocena właściwości biologicznych gleby pod uprawą szarłatu (Amaranthus cruentus L.). (Evaluation of biological properties of soil under cultivation of amaranth (Amaranthus cruentus L.). Acta Agrophysica 12(2), 527-534.

Sosnowski, J., Jankowski, K., 2013. Ocena liczebności mikroorganizmów glebowych spod uprawy mieszanek Festulolium braunii z roślina- 
mi motylkowatymi nawożonych zróżnicowanymi dawkami azotu. (Assessment of the numbers of microorganisms from soil under the mixtures of Festulolium braunii with legume plants fertilized with varying levels of nitrogen). Fragmenta Agronomica 30(4), 129-137.

Spychalski, W., Mocek, A., Gilewska, M., 2005. Potassium forms in soils formed from post-mining lands. Nawozy i nawożenie 3(24), 124-132.

Starzyk, J., Niewiadomska, A., Wolna-Maruwka, A., Swędrzyńska, D., 2013. Zmiany liczebności Azospirillum i Azotobacter w glebie pod uprawą kukurydzy (Zea mays L.) z zastosowaniem różnych nawozów organicznych. (Changes in the number of Azospirillum and Azotobacter in soil under maize cultivation (Zea mays L.) with different organic fertilizers). Fragmenta Agronomica 30(4), 147-155.

Symanowicz, B., Kalembasa, S., Skorupka, W., Niedbała, M., 2014. The changes of enzymatic activity of soil under eastern galega (Galega orientalis L.) after NPKCa fertilization. Plant, Soil and Environment 60(3), 123-128. http://doi:10.17221/905/2013-PSE

Tripathi, S., Chakraborty, A., Chakrabarti, K., Bandyopadhyay, B.K., 2007. Enzyme activities and microbial biomass in coastal soils of
India. Soil Biology and Biochemistry 39, 2840-2848. https://doi. org/10.1016/j.soilbio.2007.05.027

Vogeler, I., Vachey, A., Deurer, M., Bolan, N., 2008. Impact of plants on the microbial activity in soils with high and low levels of copper. European Journal of Soil Biology 44(1), 92-100. https://doi.org/10.1016/ j.ejsobi.2007.12.001

Xiang, S.R., Doyle, A., Holden, P.A., Schimel, J.P., 2008. Drying and rewetting effects on $\mathrm{C}$ and $\mathrm{N}$ mineralization and microbial activity in surface and subsurface California grassland soils. Soil Biology and Biochemistry 40(9), 2281-2289. https://doi.org/10.1016/ j.soilbio.2008.05.004

Yang, L., Li, T., Li, F., Lemcoff, J.H., Cohen, S., 2008. Fertilization regulates soil enzymatic activity and fertility dynamics in cucumber field. Scientia Horticultureae 116(1), 21-26. https://doi.org/10.1016/ j.scienta.2007.11.001

Zhao, Y., Wang, P., Li, J., Chen, Y., Ying, X., Liu, S., 2009. The effect of two organic manures on soil properties and crop yields on a temperate calcareous soil under a wheat-maize cropping system. European Journal of Agronomy 31(1), 36-42. https://doi.org/10.1016/ j.eja.2009.03.001

\author{
Słowa kluczowe \\ Mikroorganizmy glebowe \\ Aktywność enzymatyczna \\ Regosols \\ Rekultywacja
}

\section{Wpływ wieloletniej rekultywacji na właściwości mikrobiologiczne gleb wytworzonych z gruntów pogórniczych}

\section{Streszczenie}

Celem przeprowadzonych badań laboratoryjnych było oznaczenie aktywności enzymatycznej - dehydrogenaz, ureazy, fosfatazy zasadowej i proteaz w glebach tworzących się z gruntów pogórniczych. Ponadto określono liczebności heterotroficznych bakterii, grzybów pleśniowych, promieniowców, a także bakterii z rodzaju Azotobacter sp.. Badania prowadzono w latach 2015-2017 na powierzchniach doświadczalnych, należących do Katedry Gleboznawstwa i Rekultywacji Uniwersytetu Przyrodniczego w Poznaniu, na zwałowisku Pątnów. Próbki do analiz pobrano z dwóch warstw gleby 0-30 cm i 30-60 cm. Pierwszym badanym czynnikiem były dwa uproszczone płodozmiany: rzepakowo-zbożowy (naprzemienna uprawa pszenicy oraz rzepaku ozimego) oraz paszowo-zbożowy (uprawa przez cztery lata lucerny z trawami, a przez kolejne dwa lata pszenicy ozimej). Drugim czynnikiem w ramach podbloków były 3 wzrastające poziomy nawożenia mineralnego (azotu, fosforu i potasu) odpowiednio: 0 NPK, 1NPK oraz 2NPK. Otrzymane wyniki badań poddano analizie wariancji jednoczynnikowej, a grupy jednorodne wyznaczono testem Tukeya na poziomie istotności $a=0,05$. Obliczenia statystyczne wykonano w programie Statistica 13.1. Powstałe gleby należą do gleb Calcaric Regosols (IUSS Working Group WRB, 2015). Przeprowadzone analizy wykazały, iż aktywność mikrobiologiczna badanych gleb charakteryzowała się dużą zmiennością zarówno w sezonie wegetacyjnym, jak i w kolejnych latach prowadzonych badań. Spośród zastosowanego systemu zmianowania, korzystniejszy wpływ na aktywność mikrobiologiczną i biochemiczną wywierał płodozmian paszowo-zbożowy. Zatem przy rekultywacji gleb kształtujących się na pokopalnianych zwałowiskach wewnętrznych wskazane jest stosowanie tego płodozmianu. 